\title{
New Tendencies in Czech Minority Policy
}

\author{
Tadeusz SIWEK, Ostrava*
}

with 2 tables in the text

\section{Content}

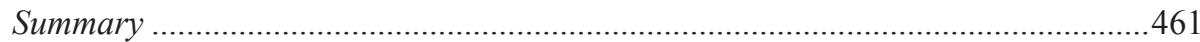

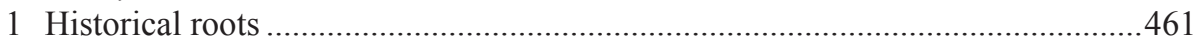

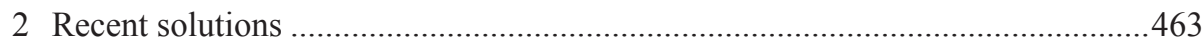

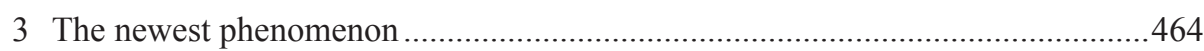

4 Conclusion: the new problem has to be solved ...................................................467

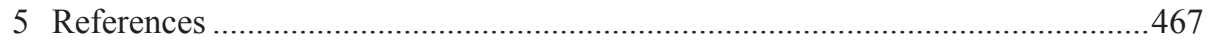

\section{Summary}

The paper presents a survey over the development of ethnic minorities on the territory of modern Czechia, examines current Czech legislation related to ethnic minorities and highlights finally new tendencies in this context becoming apparent by the Czech population census 2011, especially the significant trend towards not declaring one's own ethnicity. The paper demonstrates that this trend results in a problem with the application of minority rights that needs to be solved.

\section{Historical roots}

Minority policy on the territory of modern Czechia has a long tradition because this area was not ethnically homogenous for all its history. Besides the majority of

* Prof. RNDr. Tadeusz Siwek CSc., Ostrava University, Faculty of Natural Sciences, Chair of Geography and Regional Development, Chittussiho 10, CZ-71000 Slezská Ostrava, Czechia; email: Tadeusz.Siwek@osu.cz 
Czechs, it was settled by many minorities. Two of them were important in the past: Germans and Jews.

German population formed one quarter to one third of the Czech population, predominantly in Sudetenland - a long strip of territory in the Czech-German borderland surrounding the core of the Czech area - from the $12^{\text {th }}$ century onward. Germans were invited to Bohemia [Čechy], Moravia [Morava] and Silesia [Slezsko] by Bohemian kings as colonists of bare lands. The Kingdom of Bohemia was a part of the medieval Holy Roman Empire, which was a federation of mostly German states. Czechs and Germans lived altogether in many places and at least a partial knowledge of the second language was quite common. Nevertheless, since the second half of the $19^{\text {th }}$ century, Czechs and Germans created in the Czech lands separate cultural, political and economic institutions, which kept both groups isolated from each other. Nationalism aroused at that time as in the other European countries (AGNEw 2004).

Jews lived here dispersed on all the territory, concentrated mostly in the cities, especially in the biggest ones: Prague [Praha], Brno, and Olomouc. Some of them were slowly assimilating to German or Czech communities form the end of the $19^{\text {th }}$ century on.

Austrian minority policy tried to balance connections between different ethnic groups on the territory of the Monarchy. Some periods were better, some were worse, but the general tendency was similar to the other European democratic states. Minority rights were at that time dependent on the size of the minority. Thus, the official censuses were very important. They were organised by the Austrian government in this area from 1869 onward, and ethnicity measured by language use was documented beginning in 1880 (ŠSAMANOVÁ 2005).

Austrian minority policy was perpetuated by inter-war Czechoslovakia between 1918 and 1939, a multi-ethnic state similar to the Austrian-Hungarian Monarchy, but smaller. The Czechs and Slovaks were now the main ethnic groups, and the others were regarded as minorities: three million Sudeten Germans, 0.5 million Hungarians only in the territory of Slovakia and 100,000 Poles in the disputed area of Teschen [Těšín/ Cieszyn] Silesia as well as dispersed Jews and Ruthenians in Sub-Carpathian Ruthenia [Zakarpattja] - outside modern Czech territory and nowadays a part of Ukraine.

World War II was a disaster for two historical minorities in Czechia, Jews and Germans. The Jews were killed by Germans during Holocaust, and the Germans were later expelled to post-war Germany. Czechoslovak minority policy during the first post-war years (1945-1948) was influenced by strong anti-German tendencies among the majority of the population as well as among political parties.

New minority structures in Czechia appeared during the Communist regime (19481989). Slovaks and Roma replaced Germans and Jews, who had almost disappeared. The Polish minority survived in Teschen Silesia. Communist minority policy after 1948 was shaped by the hegemony of the Communist party. Communist ideology was superior to rights of minorities. On the one hand minorities had some rights and 
their organisations were even paid by the state budget, on the other they had to accept Communist ideology. This meant that only one organisation representing a minority was allowed and that the top management of this organisation was predominantly composed of Communists.

It is strange, that Roma, though numerous, were excluded from being considered a minority group. Communist authorities considered them as a primitive population in need to be cultivated. Communists tried to assimilate them by dispersing them from their concentration areas in Eastern and Southern Slovakia all over the country. Due to this policy, Roma appeared in all Czechoslovak towns and cities.

Roma policy followed quite different principles. Roma people were defined as a community of different nature not to be compared with other minorities and had a different status, i.e. "citizens of Gypsy origin". Roma policy was officially heading at social integration, but its aim was in fact assimilation (GRONEMEYER 1983).

\section{Recent solutions}

After 1989, totalitarian minority policy was abandoned in Czechoslovakia and a new modern minority policy was adopted step by step (HošKové 1999). After the dividing of Czechoslovakia in 1993, the modern tendencies were continued in Czechia and Slovakia as well. First changes were cosmetic only, but new rules were included into the Czech law system by Minority Act, No 273/2001 Coll. (Government CounciL for National Minorities, online). The Minority Act defines the basic terms national minority and member of a national minority. The Czech legal system differentiates between traditional minorities living in Czechia for a long time and relatively 'fresh' immigrants living here only several years. Czech law does not state any time needed for traditional minorities as for example Polish law, which demands 100 years of residence in Poland. The main difference between traditional minorities and immigrants is formal: members of traditional minorities are Czech citizens with non-Czech identity and immigrants are foreigners.

Traditional minorities recognised by the Czech Minority Act are: Slovaks, Poles, Germans, Hungarians, Greeks, Ukrainians, Belarusians, Bulgarians, Russians, Ruthenians, Serbs, Croatians, Roma and Vietnamese (Government Council fOR NAtional MinORities, online). The last minority mentioned is an example for a friendly approach of Czech authorities to this minority, because the Vietnamese have lived on Czech territory only for 50 years and only a smaller number of them are Czech citizens, but it is expected that their number will increase in the near future.

The Czech Minority Act has created the Council for Minorities as an advisory body of the Czech government. The Council is chaired by a Government member, appointed by the Government upon the proposal of the Prime Minister. The Council has two chairpersons, the first one represents public administration, the second the 
national minorities. The Council as a whole has two kinds of members: The first are representatives of state institutions such as ministries, for example finances, culture, education etc. The second part of the Council consists of representatives of the 14 minorities named above (Government Council for National Minorities, online). A demand to be represented in this council is necessary. The Jewish minority, e.g., is not a member of this body, because it did not declare a demand to be there. The specific position of the Roma minority is indicated by the fact, that their problems are dealt with by two government bodies: Besides the Council for National Minorities exists also a Commission for Roma Community Affairs (Commission for Roma Community AfFAIRS, online).

The Council is a guard for minorities' rights. Among these rights are the right to have signs within the municipalities also in their language, the right to receive information about elections in their language (both if the minority comprises at least $10 \%$ of the municipality's population), the right to education in their language as well as cultural rights including state support for the preservation of traditions.

Members of the officially recognised minorities have some basic rights, e.g., the right to use their language in communication with authorities and in front of the courts of law or the right for education in their own language (in the case of a sufficient number of children). Most of these rights are bound to a minimum number of minority members. This seems to be clear, but it is not. The first version of the Minority Act, e.g., stipulated that bilingual geographical naming for populated places, streets, squares, buildings of government bodies and territorial self-governing units could be applied only in populated places with a $10 \%$ minimum share of minorities in the total number of inhabitants and if at least $40 \%$ of adult citizens ask for this by petition. It was hard to fulfil this demand, because while the number of minority members in every municipality was documented by the census, nobody knew who affiliated themselves to a certain minority. How should then a petition be organised? In some cases, petitions were signed by Czechs, e.g., married with a minority member. Many minority members also avoided signing a petition. Later, the law was modified and it is more favourable for minorities now. For bilingual signs in public space, e.g., not anymore a petition is required. It is sufficient, when the Committee for Minorities in a municipality with $10 \%$ share of minorities asks the local authority for their implementation. The only exact criterion remaining is a minimum share of $10 \%$ in the local population according to census. The problem, however, is that the last census is invalid as a source of data of minority members.

\section{The newest phenomenon}

The last population census was held in Czechia in 2011 - as in most European Union countries. Over 6.7 million respondents declared themselves to be Czechs and 
more than 520,000 as Moravians (in the sense of a regional identity, over which exists dispute whether it corresponds to the concept of ethnicity or not) and almost 150,000 as Slovaks. No other minority did exceed the number of 60,000 . These numbers are exact, but are they really valid? Only 13,500 people, e.g., declared a Roma ethnicity, including people declaring dual identity with one of them Roma identity (CZECH Statistical Office 2011). Czech experts estimate the real number of Roma to between 10 and 20 times higher than the number recorded (KaLiBové 2001).

The worse is a quite new phenomenon in the last Czech population census: avoiding the question of ethnicity and religiosity by a big part of the Czech population. Almost 2.7 million people ignored the question of their ethnicity with the last census, and this is the biggest change in comparison with all former censuses on the territory of modern Czechia organised from 1869 onward. Table 1 shows the results of this census.

Table 1: Ethnicity according to population census 2011 in Czechia

\begin{tabular}{|l|r|r|}
\hline $\begin{array}{c}\text { Population by ethnicity } \\
\text { of } \text { which: }\end{array}$ & Number & \multicolumn{1}{c|}{$\%$} \\
\hline Czech & $6,711,624$ & 64.31 \\
\hline Moravian & 521,801 & 5.00 \\
\hline Slovak & 147,152 & 1.41 \\
\hline Ukrainian & 53,253 & 0.51 \\
\hline Polish & 39,096 & 0.37 \\
\hline Vietnamese & 29,660 & 0.28 \\
\hline German & 18,658 & 0.18 \\
\hline Russian & 17,872 & 0.17 \\
\hline Silesian & 12,214 & 0.12 \\
\hline Hungarian & 8,920 & 0.09 \\
\hline Roma & 5,135 & 0.05 \\
\hline Dual ethnicity and other & 228,507 & 2.19 \\
\hline Not declared & $2,642,666$ & 25.32 \\
\hline Total & $\mathbf{1 0 , 4 3 6 , 5 6 0}$ & $\mathbf{1 0 0 . 0 0}$ \\
\hline
\end{tabular}

Source: Czech Statistical Office 2011

Avoiding a declaration of ethnicity had appeared already in earlier censuses. But there it was a marginal phenomenon that could be considered as a statistical mistake. Till 1991 declaration of ethnicity was obligatory and avoiding declaration was negligible: $9,947(0.10 \%)$ in the census 1970, 21,036 (0.20\%) in the census 1980 
and 22,017 (0.20\%) in the census 1991 (Š́amanová 2005). Even in the census 2001, when declaration of ethnicity was not obligatory, only 172,827 inhabitants of Czechia did not declare any ethnic (or national in Czech terms) identity. It was a little bit more than before, but in fact only $1.69 \%$ of the total Czech population (CzECH STATISTICAL OfFICE 2001).

Detailed results of the last Czech census show that the phenomenon not to declare ethnicity is spread almost equally all over the territory of Czechia. It is present in all Czech regions, in big cities and small towns and in the villages as well. Regional differences are very small. Who, then, are the people not declaring their ethnicity? A part of them are persons, who are against a census as an act of invasion of the authority into the personal sphere of citizens. Some of them believe that ethnicity is an outdated concept not compatible to the $21^{\text {st }}$ century. A third group are people with unclear identity, living for example in a borderland, children living in ethnically mixed families, etc. Their identity is revealed by their mother tongue, which was declared more often than ethnicity (Table 2).

Table 2: Mother tongue of people, who did not declare ethnicity with the Czech census 2011

\begin{tabular}{|l|r|r|r|}
\hline Mother tongue & $\begin{array}{c}\text { Total number of } \\
\text { people who declared } \\
\text { mother tongue }\end{array}$ & $\begin{array}{c}\text { Did not declare } \\
\text { ethnicity }\end{array}$ & $\begin{array}{c}\text { \% of these, who } \\
\text { declared mother } \\
\text { tongue }\end{array}$ \\
\hline Czech & $9,263,300$ & $2,084,234$ & 22.50 \\
\hline Slovak & 154,465 & 32,816 & 21.24 \\
\hline Moravian & 62,908 & 3,125 & 4.97 \\
\hline Ukrainian & 48,250 & 11,348 & 23.52 \\
\hline Polish & 33,597 & 3,597 & 10.71 \\
\hline Russian & 31,622 & 9,354 & 29.58 \\
\hline Vietnamese & 30,830 & 10,944 & 35.50 \\
\hline German & 14,148 & 3,177 & 22.46 \\
\hline Hungarian & 9,286 & 2,029 & 21.85 \\
\hline Romanese & 4,919 & 1,607 & 32.67 \\
\hline Two languages and other & $\mathbf{7 8 3 , 2 3 5}$ & 480,435 & 61.34 \\
\hline Total & $\mathbf{1 0 , 4 3 0 , 5 6 0}$ & $\mathbf{2 , 6 4 2 , 6 6 6}$ & $\mathbf{2 5 . 3 4}$ \\
\hline
\end{tabular}

Source: Czech Statistical Office 2011

Table 2 shows similar shares of different ethnic groups identified by languages, who did not declare ethnicity: they vary between 20 and 30\%. Extremely small is the share among people declaring to speak Moravian, but this is a consequence of the fact 
that a Moravian standard language does not exist. Moravian is a group of dialects. Small is the number also among Poles, probably because it is a traditional minority strongly connected with their region Teschen Silesia.

On the opposite are minorities with a high share of members, who did not declare ethnicity while declaring their linguistic affiliation: Vietnamese, Roma and Russians. Vietnamese and Russian minorities are relatively new ones and they are perhaps not yet decided whether to stay and get integrated into the Czech majority or not. The largest share not declaring ethnicity exists - as expected - among people with two languages, i.e. inhabitants of borderlands - not in a geographical, but in a cultural sense: more than $60 \%$ !

\section{Conclusion: the new problem has to be solved}

Czech minority policy faces a new problem today. Many regulations based on the number of minority members are still valid, but results of censuses have ceased to be relevant criteria. A quarter of population ignoring ethnic statistics, which had been a permanent part of every Czech census from 1880, as well as about 5\% bilingual population with two ethnic identities are confusing. Some new interpretations of this situation have emerged recently. Czech authorities try to use census data as being relevant as before, but some minorities try to interpret the new phenomenon to their own advantage. They count minority shares only as shares in the population with declared ethnicity or even only as shares in the population of declared Czech identity. This is opposed to the fact that the tendency not to declare ethnicity actually reduces the shares of any ethnic group in the whole population. This question must be solved, but nobody knows a solution till now. It is within any doubt in the competence of the Czech Government, and the Council for National Minorities has also an important role to play.

\section{References}

Agnew H. (2004), The Czechs and the Lands of Bohemian Crown (= Hoover Institution Press Publication, 526), Stanford (CA), Leland Stanford Junior University.

Commision for Roma Community Affairs < http://www.vlada.cz/en/ppov/zalezitosti-romskekomunity/the-council-for-roma-community-affairs>

Czech Statistical Office (ed.) (2001), The Results of Census $2001<$ http://www.czso.cz>

Czech Statistical Office (ed.) (2011), The Results of Census $2011<$ http://www.czso.cz $>$

Government Council for National Minorities < http://www.vlada.cz/en/ppov/rnm> 
GronemEYeR R. (1983), Zigeunerpolitik in sozialistischen Ländern Osteuropas am Beispiel der Länder Ungarn, Tschechoslowakei, Polen. In: GronemeYer R. (ed.), Eigensinn und Hilfe. Zigeuner in der Sozialpolitik heutiger Leistungsgesellschaften, pp. 43-183. Giessen, Focus Verlag.

HošKová M. (1999), Die Rechtsstellung der Minderheiten in der Tschechischen Republik. In: Brunner G., Meissner B. (eds.), Das Recht der nationalen Minderheiten in Osteruropa, pp. 91-112. Berlin, Berlin Verlag Arno Spitz.

Kalibová K. (2001), Romové v Evropě z pohledu demografie. In: Demografie, 2, pp. 125-132.

Šamanová G. (2005), Národnost ve sčítání lidu v českých zemích. In: Naše společnost, 1. $<$ http://www.soc.cas.cz> 